\title{
DONATIONS TO THE STATE HISTORICAL SOCIETY.
}

The Biennial Report of Prof. Parvin, late Corresponding Secretary, to the Governor, submitted for their approval, to the Board of Curators, shows the following contributions to have been made by the persons named below to the collec tions of the Society:

DONATIONS TO IIBRARY.

Abbott, Mrs.-Photograph of Col. Abbott.

American Geological and Statistical Society-Proceedings 1862-3 and 1863-4.

Baily, J. W. C.-Illinois Gazeteer, 1864.

Bronson, C. M-Law Docket, Johnson County, 1840.

Brown, T. L., Ct.-Copy Connecticut Courant, Oct. 29, 1764. Baird, Dr. S. J., Woodbury, N. J.-Two Pamphlets, "Training of Children," "Southern Rights and Northern Duties." Coleman, Judge, Columbus City-Address by himself. Clark, J. N.-Pamphlet.

Chicago Hist. Society-Historical Sketch of early movements in Illinois for Legalization of Slavery, by W. H. Brown, 1865-Annual Report Board of Public Works-Seventh Annual Statement Trade and Commerce of Chicago:

Dakota Hist. Society-Map of Territory.

Ealy, Dr. J. H.-Italian MS. of 1559, concerning the Execution of the Cenci Family.

Everett, Sam., Michigan-Baxter's Call, 1818-Second Coming of Christ, 1838.

Guilbert, Dr. E. A.-MS. Reports of Gen. Jeff. C. Davis to Gen. Lyon, June, 1861.

Gardner, John-Old Revolutionary Paper:

General Land Office Report, State Dep't, Washington. Guilbert, W. L.-Photographic View of Old Settlers, Protestant Clergy and Catholic Priests of Dubuque.

Hartsock, J. P.-Six Miscellaneous Pamphlets. 
Harlan, Hon. Jas.-Twenty Vols. Congressional Documents. Irish, Capt. F. M., Iowa City - "Timepiece," a newspaper published in New York in 1797.

Kasson, Hon. J. A.-Congressional Directory XXVIIIth Congress, 1st Session.

Levering, N.-Short Treatise on Church Discipline, printed by Franklin in 1743 .

Longworth, Ed., Dubuque - Photograph of himself-Three

Journals of Wisconsin and Iowa, 1836, 1839, 1840.

Mann, Dr. T.-Sketch of James L. Longworth.

Naval Observatory, Washington-Astronomical and Meteorol. ogical Observation-Eleven Vols. Nautical Almanac, 1855-65.

New Jersey Hist. Society-Records of Newark, N. J., 1666 to 1836-Vol. 10, No. 1, of Proceedings of N. J. Hist. Society.

New England Hist. and Geneolog. Society—Eulogy on President Lincoln.

Parker, Prof. L. H.-History of Poweshiek County.

Parker, Col.-An original Commission issued by Gov. Clark to a Lowell Company, dated July 25, 1815.

Parvin, T. S.-Proceedings Grand Lodge of Iowa-Map of New York, 1837-1st and 2d Annual Rep. U. S. Christ. Com., 1862-63 - Sundry Pamphlets-Charter Grand Division Sons of Temperance, 1847-Notes of the Miners' Bank, Dubuque, 1858-Annual Report Boston Y. M. Christian Association, 1865-Proceedings Grand Lodge of Iowa, 1864-5-Photograph of Col. Benton-Photograph of himself-Proceedings of Old Settlers' Association, Dubuque.

Ryan, Mortimer, Iowa City-Large Atlas of the World, 1800. Ruben, A. A.-Report Y. M. Merc. Library Ass'n, N.Y., 1865. Rice, Gen. S. A.-Photograph of himself. Smith, H. A., Cleveland, O.-City Scrip of Cleveland. Sale, William, Iowa City-Report on Water and Sediment of Mississippi River. 
Van Nest, Rev. P. S., Geneva, Wis.-Minutes of Presbyterian and Congregational Church Convention of Wis., 1862.

Wright, Hon. James-Photograph of himself-Reports Sup. Court, Vol. 16, thirty-one copies-Reports, 1865, fifty copies-Journals Senate, 1864, nine vols.-Journal House, 1864, seven vols.-Reports of State Institutions, 1864, six vols.- Iowa State Agriculturai Society, 1864, ten vols.

Williams, C. R., Vermont-Number of Autographs of Distinguished Fathers of the Republic.

Wells, Prof. D. Franklin, Iowa City-Transactions Sixth Annual Session National Teachers' Association.

DONATIONS TO CABINET.

Boucher, Dr. J. H., Iowa City-12 Confederate Bills-various denominations from $\$ 1.00$ to $\$ 100$.

Bowen, Dr. Jesse, Iowa City-Confederate States Bill, $\$ 50$. Buttre, J. A., N. Y-Ornamented copy Declaration Independence-Constitution United States-Washington's Farewell Address.

Crosby, J. O., Garnavillo-MS. picked up at Fairfax Court House, dated 1776.

Cochran, Dr. M. B., Iowa City-Chain taken from ankle of Slave in Dixie-Wooden Mortar used by Federals at the Siege of Mobile.

Clarke, Colonel W. Penn, Iowa City-Three Lithographic Views - Chattanooga - Tulah Falls, and Officers of a Michigan Regiment on Lookout Mountain.

Dameude, J. L.-Nine Jars of Reptiles in Alcohol.

Davis, J. W.-Petrified Wood from Dacotah.

Duncan, Major L. A.-Hand Grenade-Signal Lights from Dixic.

Detwiller, C., Tipton-Osage Orange.

Ealy, Dr. J. H., Iowa City-Fragment of Crinoidal Vase from Dixie.

Fellows, C. Sumner-Connecticut Scrip, 1775.

Fry, Harriet, Iowa City - Sprigs of Evergreen firom Pulaski's Monument at Savannah. 
Hartsock, Virgil,-Jackson Election Ticket, 1832.

Hempstead, Dexter-Indian Arrow Head.

Hoopes, B. F.-A Naval Sword, captured at Chickamauga from rebels.

Jones, Mrs. George-Virginia Currency of 1792 .

Lee, Wm., Rock Island-Three Specimens gold-bearing Ore from Pike's Peak.

McAllister, J. A.-Copper-Plate Engraving of Old State House, Dubuque.

Myers, Frank C.-Full Set Confederate Notes, from 50 cts. to $\$ 500$-Also Rebel 7-30 Bond.

Meek, Jos., A. J. Millard, H. A. Berry, Col. Pattee, A. Marshall and $\mathrm{H}$. $\mathrm{N}$. Levering-Various Articles of Indian Wear and Weapons picked up on the battle field of White Stone Hill, Dacotah, Sept. 3, 1863.

Parvin, T. S-Six Specimens of Rocks of Lake Superiorand two of gold-bearing Quartz from Colorado.

Templin, J. W.-Piece of Wood from Coal Mine at Blairstown, found 30 feet below ground.

\section{FLAGS-INFANTRY,}

1st Regiment-Flag of Co. A, carried at the battle of Wilson's Creek, presented through Gov. Kirkwood, in 1861.

2nd Regiment-Flag carried at battle of Fort Donelson, presented through Gov. Kirkwood in 1862.

5th Regiment, (consolidated with the 5th Cavalry)-Regimental and National Flags, presented through Adjt. Gen. Baker in 1864.

9th Regiment-Flags presented in 1865, through Lieut. Col. Abernethy and Adjt. Gen. Baker.

10th Regiment-Flag carried in fight at New Madrid, presented in 1863, through Col. Small-and that carried at Island No. 10, Iuka and Corinth, through Adjt. Gen. Baker.

13th Regiment-Two Flags, presented through Adjt. Gen, Baker. 
14th Regiment-The Regimental and National Colors of this Regiment, carried at Fort Donelson and other battles, presented through Adjt. Gen. Baker in 1864.

15th Regiment-The Flag carried at Shiloh, presented in 1862, through Gov. Kirkwood-Two others presented in 1865 through Adjt. Gen. Baker.

18th Regiment-Two Flags, sent throngh Adjt. Gen. Baker, 1865 .

21st Regiment-Two Flags presented through Adjt. Gen. Baker-and one through Capt D. J. Davis.

26th Regiment-Flag presented through Adjt. Gen. Baker.

30th Regiment-Two Flags presented by Adjt. Gen. Baker, and one throngh $\mathrm{Col}$. Torrence.

31st Regiment-Flag presented throngh Adjt. Gen. Baker. 32nd Regiment-Flag presented through Adjt. Gen. Baker. 39th Regiment-Flags presented through Adjt. Gen. Baker.

\section{CAVALRY.}

2nd Regiment-Flag presented by Adjt. Gen. Baker. 4th Regiment-Flag presented through Adjt. Gen. Baker. 5th Regiment-Flags presented by Gen. Slew.

6th Regiment-Flag's presented through Adjutant Gen. Baker.

7th Regiment-Flag borne in North-Western Campaigns, presented in 1863 by Major H. H. Heath.

\section{ARTILLERY.}

1st Battery-Flag presented Aug. 1st, 1865, through Adjt. Gen. Baker.

2nd Battery-Flag presented (torn) through Adjt. Gen. Baker.

8d Battery-Flag presented April I2th, I865, through Adjt. Gen. Baker. 
Copyright of Annals of Iowa is the property of State of Iowa, by \& through the State Historical Society of Iowa and its content may not be copied or emailed to multiple sites or posted to a listserv without the copyright holder's express written permission. However, users may print, download, or email articles for individual use. 